\title{
IDENTIFIKASI SENYAWA MYCOSPORINE-LIKE AMINO ACIDS DARI FRAKSI ETANOL Eucheuma cottonii MENGGUNAKAN SPEKTROFOTOMETER UV
}

\author{
Reymon, Subehan Lallo dan Marianti A. Manggau \\ Fakultas Farmasi, Universitas Hasanuddin, Makassar
}

Kata Kunci :

UV-A, MAAs, Eucheuma cottonii

06-08-2018

$\begin{array}{lr}\text { Revisi } & 26-08-2018 \\ \text { Diterima } & 30-08-2018\end{array}$

\section{Korespondensi}

\section{Marianti A Manggau}

winati04@yahoo.co.id

\section{Copyright}

(C) 2018 Majalah Farmasi Farmakologi Fakultas

Farmasi $\cdot$ Makassar

Diterbitkan tanggal 31-08-2018

Dapat Diakses Daring Pada:

http://journal.unhas.ac.id /index.php/mff

\begin{abstract}
ABSTRAK
UV-A merupakan sinar UV yang berpenetrasi paling dalam pada kulit dan dapat menyebabkan kerusakan kulit hingga penuaan dini. Paparan sinar UV-A dalam waktu yang lama dapat menyebabkan kerusakan pada jaringan dermis kulit, pigmentasi dan kanker kulit. Perlindungan kulit terhadap sinar UV-A yaitu dengan menggunakan bahan anti UV-A. Senyawa yang berperan sebagai anti UV-A di alam, salah satunya Mycosporine-like Amino Acids (MAAs). Senyawa ini terdapat dalam organisme laut seperti cyanobakteri, mikroalga dan makroalga. Eucheuma cottonii merupakan salah satu makroalga merah yang diduga mengandung MAAs. Tujuan dari penelitian ini untuk mengidentifikasi senyawa MAAs dari fraksi etanol Eucheuma cottonii yang diperoleh dari pantai kepulauan Selayar. Sampel dicuci hingga kadar garamnya berkurang, diliofilisasi menggunakan freeze dryer dan diektraksi dengan maserasi menggunakan pelarut etanol 70\%. Ekstrak cair yang diperoleh diuapkan dengan rotavapor hingga didapatkan ekstrak kering. Ekstrak kemudian difraksinasi dan diidentifikasi menggunakan spektrofotometer UV. Fraksi yang diperoleh sebanyak 6 yang kemudian diidentifikasi menggunakan spektrofotmeter UV dan FT IR. Hasil identifikasi menunjukkan jika senyawa yang terdapat pada fraksi 4 dan 6 tidak menunjukkan adanya senyawa MAAs, sedangkan fraksi 1 dan 3 terdapat senyawa pengotor sehingga tidak dapat dipastikan mengandung senyawa MAAs. Fraksi 2 dan 5 menunjukkan kemungkinan adanya senyawa MAAs. Disimpulkan bahwa fraksi etanol 2 dan 5 dari Eucheuma cottonii kemungkinan mengandung senyawa MAAs.
\end{abstract}

\section{PENDAHULUAN}

Radiasi sinar ultraviolet (UV) matahari diketahui sebagai salah satu faktor utama yang dapat menyebabkan kerusakan pada level molekuler, terdapat bukti bahwa radiasi UV merusak DNA pada sel kulit manusia dengan menghasilkan senyawa secara langsung maupun tidak langsung dengan meningkatkan level reactive oxygen species (ROS), radikal superoksida $\left(\mathrm{O}_{2} \cdot\right)$, hidrogen peroksida $\left(\mathrm{H}_{2} \mathrm{O}_{2}\right)$ dan radikal hidroksil $(\mathrm{OH} \cdot)$, memicu oksidasi DNA, RNA, lipid dan protein yang dapat memicu perubahan pada lingkungan sel (1).

Mycosporine-like amino acids (MAAs) adalah senyawa yang terdapat dalam organisme laut yang mengabsorbsi radiasi UV-A dan UV-B. MAAs telah diidentifikasi pada berbagai organisme laut seperti fitoplankton, invertebrata, mikroalga, dan makroalga. Kandungan senyawa MAAs pada organisme laut dapat berbeda satu sama lain (2). Senyawa MAAs yang telah ditemukan pada organisme laut diantaranya adalah porphyra-334 (P-334) dari alga merah Porphyra. Shinorine (SH) dan mycosporine-glycine (M-Gly) pertama kali diidentifikasi dari Palythoa tuberculosa, mycosporine-taurine (M-Tau) yang diisolasi dari anemon laut Anthopleura elegantissima dan mycosporine-Alanine (M-Ala) dari Colletotrichum graminicola (3).

Eucheuma cottonii merupakan salah satu makroalga merah yang dibudidayakan diperairan Sulawesi Selatan untuk diambil kandungan karagenan dan agarnya. Khasiat Eucheuma cottonii sebagai tanaman yang mengandung senyawa MAAs belum pernah diteliti sebelumnya.
Dengan demikian, penelitian tentang kandungan MAAs pada Eucheuma cottonii perlu dilakukan. Penelitian ini bertujuan untuk mengidentifikasi senyawa Mycosporine-like Amino Acids (MAAs) dari fraksi etanol Eucheuma cottonii menggunakan spektrofotometer UV.

\section{METODE PENELITIAN}

\section{Alat dan Bahan Penelitian}

Peralatan yang digunakan adalah freeze dryer, lumpang, stamper, blender, ayakan no. 40, timbangan digital, peralatan gelas laboratorium, kromatografi kolom dan spektrofotometer UV .

Bahan yang digunakan adalah Kertas saring, aquadest, etanol $70 \%$, amonium asetat $1 \mathrm{mM}$, asam asetat $0,1 \%$, etil asetat asetonitril, isopropanol, asam formiat dan metanol.

\section{Penyiapan Sampel}

Sampel diambil dari petani rumput laut di Dusun Toru Desa Bungaiya, Kecamatan Bontomatene, Kabupaten kepulauan Selayar, Sulawesi Selatan. Sampel rumput laut yang diambil kemudian dimasukkan dalam cooler box yang berisi es dan air laut. Sampel kemudian dicuci dengan air mengalir sebanyak 3 kali. Setelah dicuci, sampel lalu dipotong kecil-kecil dan dimasukkan kedalam plastik dan dimasukkan kedalam lemari pendingin hingga beku. 


\section{Liofilisasi}

Sampel yang telah beku kemudian dimasukkan kedalam freeze dryer pada suhu $-60^{\circ} \mathrm{C}$ sampai kering. Selanjutnya sampel yang telah kering dihancurkan dalam lumpang kemudian diblender dan diayak menggunakan ayakan ukuran mesh 40 .

\section{Ekstraksi}

Sebanyak 3,183 kg sampel Eucheuma cottonii yang telah diserbukkan dilarutkan dalam 25 L etanol 70\% kemudian didiamkan selama 24 jam sambil sesekali diaduk. Setelah itu sampel disaring dengan kertas saring sehingga akan didapatkan ekstrak dan ampas. Kemudian ampas direndam lagi dengan pelarut yang sama. Hal ini dilakukan sebanyak 3x24 jam. Filtrat kemudian dikumpulkan dan disaring lagi dengan kertas saring. Pelarut kemudian diuapkan dengan rotary evaporator hingga diperoleh ekstrak kering.

\section{Analisis Ekstrak Menggunakan spektrofotometer UV}

Ekstrak kering ditimbang sebanyak $10 \mathrm{mg}$ dan dilarutkan dengan etanol sebanyak $2 \mathrm{ml}$. Larutan ekstrak dimasukkan kedalam kuvet dan etanol sebanyak $2 \mathrm{ml}$ dimasukkan kedalam kuvet yang lain sebagai blanko. Panjang gelombang diatur dengan absorbansi antara 268-362 nm.

\section{Fraksinasi Ekstrak Menggunakan KLT-Preparatif}

Dibuat lempeng KLTP dengan cara ditimbang $30 \mathrm{~g}$ silika gel halus dan air sebanyak 70 ml. Lempeng kaca ukuran 20 x 20 $\mathrm{cm}$ dicuci dengan air kemudian dibebas lemakkan dengan alkohol. Lempeng kaca kemudian diatur di atas cetakan.

Kemudian air ditambahkan pada silika gel sedikit demi sedikit sambil dihomogenkan di dalam erlenmeyer yang bertutup. Suspensi silika gel dituang pada kaca yang telah disiapkan sebelumnya, suspensi silika gel ditunggu mengering. Lempeng yang telah jadi diaktifkan dengan cara dipanaskan dalam oven pada suhu $110^{\circ} \mathrm{C}$ selama 3 jam.

Ekstrak yang diperoleh ditotol secara berderet sehingga membentuk seperti pita dengan pipa kapiler pada lempeng KLTP dan dielusi. Eluen yang digunakan etil asetat : isopropanol : asam formiat $(24: 1,5: 0,5)$. Setelah terelusi, lempeng dilihat pada UV $254 \mathrm{~nm}$ dan $366 \mathrm{~nm}$ dan pita dikeruk.

\section{Identifikasi senyawa Anti UV-A Fraksi Etanol Eucheuma cottonii menggunakan Spektrofotometer UV}

Fraksi-fraksi etanol dari Eucheuma cottonii yang diduga mengandung senyawa MAAs dilakukan pengujian aktivitas anti UV-A menggunakan spektrofotometer UV dengan melihat panjang gelombang maksimal dan absorbansi dari fraksi tersebut pada panjang gelombang UV-A.

\section{HASIL DAN PEMBAHASAN}

Sampel kering Eucheuma cottonii sebanyak 3,138 kg hanya menghasilkan ekstrak kering 14,2424 gram. Pengujian awal yang dilakukan menggunakan spektrofotometri UV menunjukkan bahwa ekstrak etanol Eucheuma cottonii kemungkinan mengandung senyawa MAAs yang ditunjukkan dengan panjang gelombang absobsi yang berada dikisaran 268 - 362 nm yaitu 270,40 $\mathrm{nm}$ dan 329,80 nm. Wada et al, 2015 telah mereview beberapa senyawa MAAs yang terdapat dalam makro alga dan berada dalam rentang absobsi panjang gelombang 268-362 nm. Hasil pemisahan KLTP dari ekstrak etanol Eucheuma cottonii didapatkan 6 fraksi yang kemudian dilakukan identifikasi dengan spektrofotometer UV. Pada fraksi satu (1), tampak banyak senyawa pengotor sehingga sulit dipastikan adanya senyawa MAAs dalam fraksi ini, namun panjang gelombang 334,85 $\mathrm{nm}$ dan $332,25 \mathrm{~nm}$ kemungkinan adalah senyawa MAAs. Dunlap et al, 1998 melakukan identifikasi senyawa MAAs yang mengabsorbsi radiasi UV pada organisme karang dan menemukan beberapa senyawa MAAs seperti palythinol $\left(\lambda_{\max }=332 \mathrm{~nm}\right)$, porphyra$334\left(\lambda_{\max }=334 \mathrm{~nm}\right)$. Pada fraksi 1 ini masih perlu pemisahan lanjutan untuk mengidentifikasi adanya senyawa MAAs dalam fraksi ini.

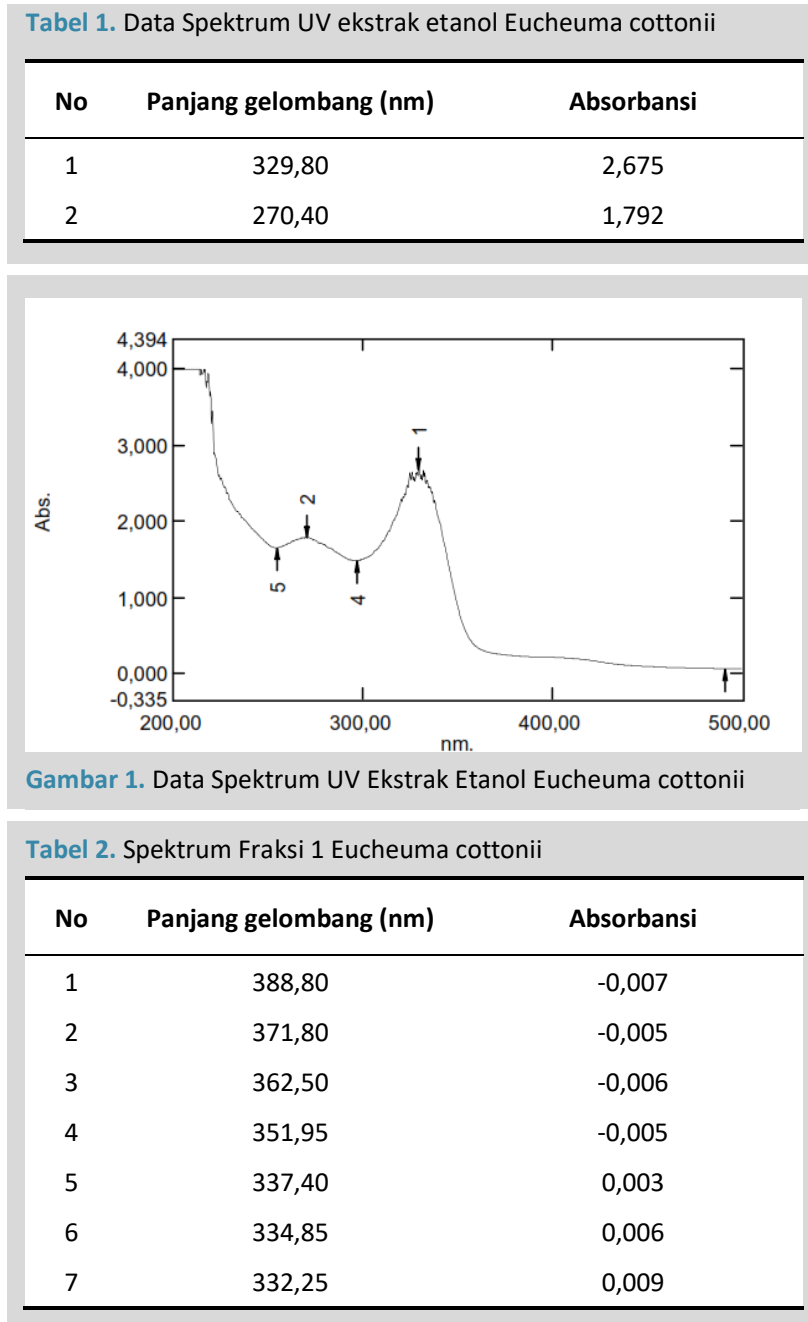

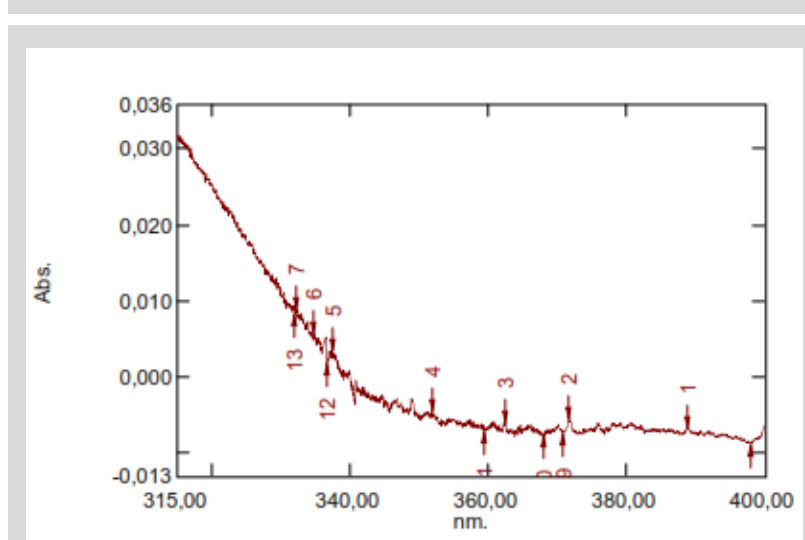

Gambar 2. Data Spektrum UV Ekstrak Etanol Eucheuma cottonii

Pada penelitian ini memperlihatkan bahwa pada fraksi dua (2) terdapat senyawa yang mengabsorbsi pada panjang gelombang 336,55 nm, Kemungkinan bahwa senyawa ini adalah golongan senyawa MAAs, seperti salah satu senyawa MAAs yang diiidentifikasi Dunlap et al, 1998 asam palythenat yang terdeteksi pada panjang gelombang $337 \mathrm{~nm}$. Pada fraksi tiga (3), tampak banyak senyawa pengotor sehingga sulit dipastikan adanya senyawa MAAs dalam fraksi ini, namun panjang gelombang 332,90 $\mathrm{nm}$ dan 334,35 kemungkinan adalah senyawa MAAs, seperti palythinol $\left(\lambda_{\max }=332 \mathrm{~nm}\right)$, 
porphyra-334 $\left(\lambda_{\max }=334 \mathrm{~nm}\right)$. Pada fraksi empat (4) tidak nampak adanya senyawa yang mengabsorbsi UV pada panjang gelombang UV-A, sehingga dapat dikatakan tidak ada senyawa yang bersifat sebagai anti UV-A.

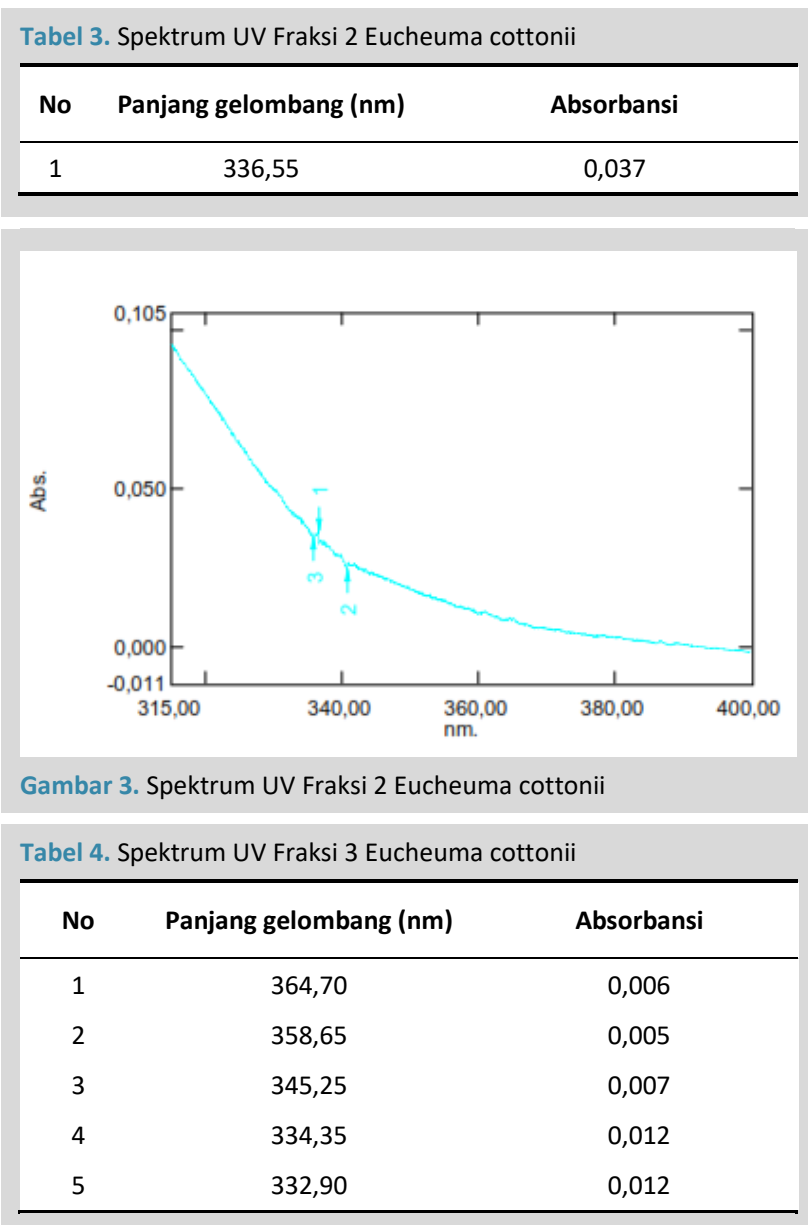

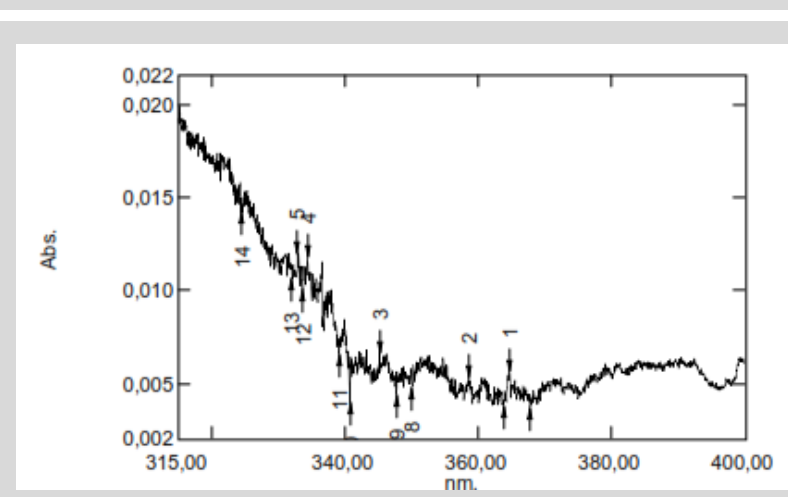

Gambar 4. Spektrum UV Fraksi 3 Eucheuma cottonii

Tabel 5. Spektrum UV Fraksi 4 Eucheuma cottonii

\begin{tabular}{lcc}
\hline No & Panjang gelombang $(\mathrm{nm})$ & Absorbansi \\
\hline- & - & - \\
\hline
\end{tabular}

Pada fraksi lima (5) terdapat senyawa yang mengabsorbsi pada panjang gelombang 339,45 $\mathrm{nm}$. Sinha et al, 2007 melakukan penelitian beberapa senyawa MAAs dan menyimpulkan bahwa senyawa MAAs berada dalam rentang panjang gelombang antara 310 - $362 \mathrm{~nm}$. Kesimpulan ini menunjukkan bahwa senyawa yang terkandung dalam fraksi 5 kemungkinan adalah senyawa MAAs. Pada fraksi enam (6) tidak nampak adanya senyawa yang mengabsorbsi UV pada panjang gelombang UV-A, sehingga dapat dikatakan tidak ada senyawa yang bersifat sebagai anti UV-A.

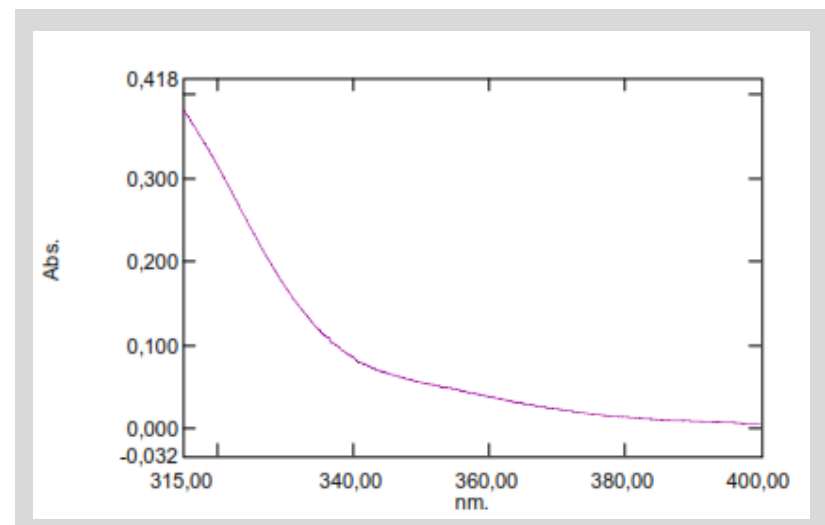

Gambar 5. Spektrum UV Fraksi 4 Eucheuma cottonii

\begin{tabular}{ccc}
\multicolumn{3}{l}{ Tabel 6. Spektrum UV Fraksi 5 Eucheuma cottonii } \\
\hline No & Panjang gelombang (nm) & Absorbansi \\
\hline 1 & 339,45 & 0,051 \\
\hline
\end{tabular}

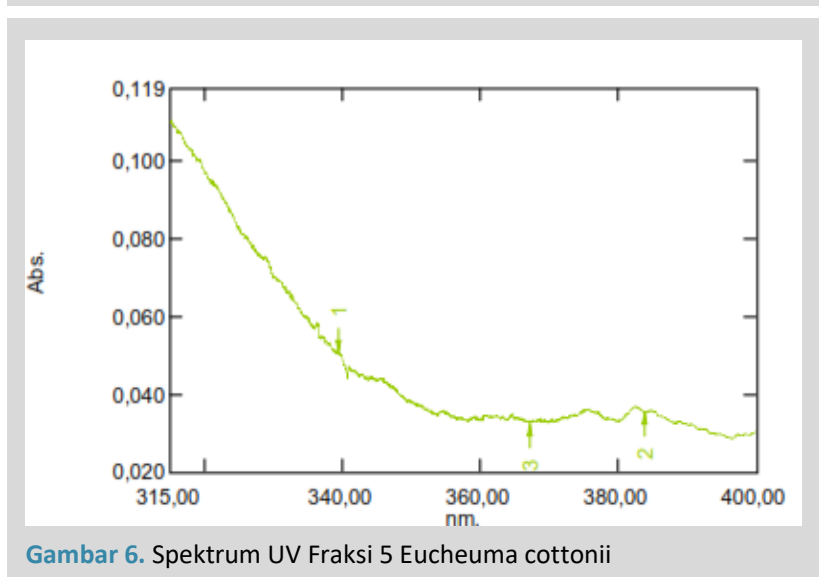

\section{KESIMPULAN}

Berdasarkan hasil penelitian yang telah dilakukan dapat disimpulkan bahwa kemungkinan senyawa MAAs dalam fraksi 2 dan fraksi 5 Eucheuma cottonii yang ditandai dengan adanya absorbsi pada rentang panjang gelombang antara 310-362 nm.

\section{DAFTAR PUSTAKA}

1. Coba, F. De La., Aguilera, J., Figueroa, F.L. 2008. Antioxidant Activity of Mycosporine-like Amino Acids Isolated from Three Red Macroalgae an One Marine Lichen. J. Appl Phycol. 21: 161-169.

2. Carefoot, T.H., Harris, M., Taylor, B.E. 1998. Mycosporine-like Amino Acids: Possible UV Protection in Eggs of The Sea Hare Aplysia dactylomela. Marine Biology. 130: 389-396.

3. Wada, Naoki., Sakamoto, Toshio., Matsugo, Seiichi. 2015. Mycosporinelike Amino Acids and Their Derivatives as Natural Antioxidants. www.mdpi.com. Antioxidants 4: 603-646.

4. Conde, F.R., Churio, M.S., Previtali, C.M. 2000. The Photoprotector Mechanism of Mycosporine-like Amino Acids. Excited-state properties and Photostability of Porphyra-334 in Aqueous Solution. Journal of Photochemistry and Photobiology B. Biology 56: 139-144.

5. Ghetti, Francesco., Checcucci, Giovanni., Bornman, Janet F. 2001. Environmental UV Radiation: Impact on Ecosystems and Human Health and Predictive Models. Earth and Environmental Sciences. Vol. 57.

6. Hartmann, Anja., Becker, Kathrin., Karsten, Ulf., Remias, Daniel., Ganzera Markus. 2015. Analysis of Mycosporine-like Amino Acids in Selected Algae and Cyanobacteria by Hydrophilic Interaction Liquid Chromatography and a Novel MAA from The Red Alga Catenella repens. Marine Drugs. 13: 6291-6305.

7. Higashi-Okai, K., Otani, S., Okai, Y. 1999. Potent Suppressive Effect of a Japanese Edible Seaweed, Enteromorpha prolifera (Sujiao-nori) on Initiation and Promotion Phases of Chemically Induced Mouse Skin Tumorigenesis. Cancer Letters. 140: 21-25.

8. Houghton, PJ., Raman. 1998. Laboratory Handbook for The Fractination of Natural Extract. Chapman an Hall. London. UK.

9. Kim, Se-Kwon. 2012. Handbook of Marine Macroalgae. Wiley-Blackwell. Pukyong National University. 
10. Lin, Rong-Feng., Feng, Xue-Xuan., Li, Chu-Wen., Zhang, Xiao-Jun., Yu, XiuTing., Zhou, Jiu-Yao., Zhang, Xie., Xie, You-Liang., Su, Zi-Ren., Zhan, Janis Ya-Xian. 2014. Prevention of UV Radiation-induced Cutaneous
Photoaging in Mice by Topical Administration of Patcholi Oil. Journal of Ethnopharmacology. 154: 408-418 